\title{
Reconstruction of urban worn-out textures and reduction in risk taking (case study: Shushtar City)
}

\author{
Fatemeh Monjezi ${ }^{1}$, Hasan Beik Mohammadi ${ }^{2}$ \\ ${ }^{1}$ Department of Geography, Payame Nor University of Shushtar, Shushtar, Iran \\ ${ }^{2}$ Research Centre of Shakhes Pajoh, University of Isfahan, Isfahan, Iran
}

\section{Email address:}

Fatememonjezi1@yahoo.com (F. Monjezi), Beikmohammadi_h@yahoo.com (H. B. Mohammadi)

\section{To cite this article:}

Fatemeh Monjezi, Hasan Beik Mohammadi. Reconstruction of Urban Worn-Out Textures and Reduction in Risk Taking (Case Study: Shushtar City). American Journal of Civil Engineering. Special Issue: Research and Practices of Civil Engineering in Developing Countries. Vol. 3, No. 2-2, 2015, pp. 24-29. doi: 10.11648/j.ajce.s.2015030202.15

\begin{abstract}
Worn - out textures for a number of reasons such as lack of technical and engineering criteria in the construction of the buildings, non - efficient communication network, lack of urban installations and facilities, are more susceptible to natural hazards. The aim of this research is to reduce risk- taking of old and worn - out textures of Shushtar City in the process of reconstruction of this texture. Tools of gathering information in this research are the desk studies, observation, using of the maps, documents and queries. SWOT strategic model has been employed and the SPSS software has been used for the data analysis. The results of this research show that in this texture, the low quality of the buildings, construction material, narrow width of passages, inability of the inhabitants in reconstruction and renovation of old and worn - out textures , makes it necessary to seek a remedy for elimination of risk-taking.
\end{abstract}

Keywords: Worn - Out Textures, Risk-Taking, Urban Planning, Reconstruction, Shushtar City

\section{Introduction}

Human efforts to confront natural disasters and calamities in modern era possess 3 stages and approaches. The first approach based on offering emergency aids and rescue and relief actions, began at early 20 century and continued till the Second World War and during which rescue aids were offered to the injured. The second approach developed after the World War II and in the atmosphere of victory of scientific and technical dialogue, and schools of growth and development and Behaviorism, following the war in America - Europe and then all over the world. And by incorporating scientific and engineering outcomes in building and development of built environment such as buildings and roads and urban construction became a priority and remained the dominant and fundamental approach till the 1980s. The third approach , considering the inadequacy of scientific and Engineering approach in confronting disasters and calamities and not enough taking into account human factors and variables in preventing disaster, gradually a new approach named crisis management approach began to form at the end of 1980s and early 1990s which based its emphasis on the reduction of individual and social human environment risk- taking against natural disasters and calamities and now is the dominant and widespread approach at the international level and in many countries of the world (1).

Old and worn-out textures are one of the many types of urban textures which, due to worn-out fabric and inappropriate possession and existing vulnerable infrastructure possess local and spatial instability (4).

The aim of urban reconstruction is the improvement of economic, spatial, natural and physical environments within and around the city. In the process of urban reconstruction, government organization, local authorities, regional development organizations, urban development companies, private developers and other business investors are involved (11).

Renovation means reconstruction of buildings and urban spaces, which through achievements or processes, the signs of weariness, destruction and lack of prosperity Disappear (5).

\section{Problem Presentation}

Natural disasters have influenced the lives of millions of people in the world and challenged the development of the nations. Despite many efforts to reduce risk-taking and 
negative impact of disasters, the risk-taking of many disasters is increasing. This increase in risk-taking is due to the increase in people and assets encountered with hazards. For example through rapid economic and urban growth in the bay area's subject to storms or earthquake prone cities (8).

Therefore the goals of this research are to define indices of weariness determination, of the urban texture as well as .

analysis and articulation of optimum guidelines for

renovation to reduce risk-taking in this area.

As disqualified materials with low durability are used in the construction of almost all existing buildings, the renovation in these textures could be an appropriate mean to reduce risk taking in this area.

The present research methodology is a combination of descriptive, documentary and analytical methods.

\section{Theoretical Bases}

Being worn-out means, disfiguration of fabric components of the city from their main shape and movement towards fabric and functional destruction of the city $(6,9)$.

The main criteria for the establishment of the process of weariness of urban texture are:

1-Micro-residential blocks, indicating tightness and intensity of the blocks, more than $50 \%$ of blocks possess less than 120 square meters.

2-fabric instability, inappropriate structural system and lack of strength in buildings.

3- Inscrutability, indicating lack of access to and appropriate network of passages-Alleys less than $6 \mathrm{~m}$ in width (7).

Hyogo's framework has 3steering goals and is the most integrated and comprehensive global framework in disaster risk reduction and management. The steering goals of Hyogo's framework are:

(A)-Integration of the most influential considerations of disaster risk reduction into the policies and sustainable development programs.

(B)-Development and strengthening of institutions, mechanisms and capacities in all levels of local communities with the aim of helping empowering confronting risks.

(C)- Introducing reduction of risk taking approaches in the design and implementation of preparedness, respond and reconstruction of hazard destructed areas (8).

Main schools in the scope of urban improvement and renovation are listed in order in the Table 1:

Table 1. Theories of improvement of worn-out textures

\begin{tabular}{ll}
\hline $\begin{array}{l}\text { Cultural } \\
\text { orientation }\end{array}$ & $\begin{array}{l}\text { Priority of spiritual needs over material ones: } \\
\text { improvement and renovation through revival of the } \\
\text { past cultural values. }\end{array}$ \\
$\begin{array}{l}\text { Progressive } \\
\text { orientation }\end{array}$ & $\begin{array}{l}\text { During renovation and reconstruction of the old } \\
\text { cities, nothing is preserved except the roads } \\
\text { Recession of old texture because of social and } \\
\text { economic groups and segregations due to social } \\
\text { Ecological school }\end{array}$ \\
\hline
\end{tabular}

\begin{tabular}{|c|c|}
\hline $\begin{array}{l}\text { Functional } \\
\text { orientation }\end{array}$ & $\begin{array}{l}\text { Improvement and renovation for the aim of } \\
\text { economic and functional development of the city }\end{array}$ \\
\hline $\begin{array}{l}\text { Structural } \\
\text { orientation }\end{array}$ & $\begin{array}{l}\text { Collective like and systemic attitude towards city: } \\
\text { improvement of fabric and spatial structures in } \\
\text { collections and not single buildings. }\end{array}$ \\
\hline Modernism & $\begin{array}{l}\text { Extreme inclination for preservation of old } \\
\text { monuments that even required the renovation and } \\
\text { improvement of dead and non-historic buildings. }\end{array}$ \\
\hline Post modernism & $\begin{array}{l}\text { Thinks more about social relationships: provoking } \\
\text { the sense of locality, revival of what that possesses } \\
\text { local and special value. }\end{array}$ \\
\hline Humanism & $\begin{array}{l}\text { Considering people and their partnership in } \\
\text { improvement and renovation of urban space and } \\
\text { people-oriented intervention. }\end{array}$ \\
\hline
\end{tabular}

Source: (1)

\section{Museum-Like Attitude towards Urban Texture}

This view is based on the preservation of cultural heritage and does not accept intervention in the old and historical textures, unless for their preservation. This attitude believes that the old texture should be preserved like things existing in a museum. This view has sheer emphasis on this that by least intervention in the buildings and urban elements should be preserved. In this attitude preservation of identity and heritage of ancestors are prioritized over requirements of contemporary life. In consequence the inhabitants of these textures, because of not applying the required changes in today's everyday life and shortages and insufficiencies of urban infrastructures which have roots in such insight, have been forced to leave the texture and after collapse of social texture, follows the destruction of fabric texture (3).

\section{Location of Study Area}

Shushtar City has an area of 2436 square kilometers, and is located between $48^{\circ}, 35^{\prime}$ and $49^{\circ}, 12^{\prime}$ from Greenwich Meridian and between $31^{\circ}, 36^{\prime}$ and $32^{\circ}, 26^{\prime}$ from Equator, at the north of Khuzestan Province. Its population is about 111200 (according to census 1390) and is $57^{\text {th }}$ city of Iran according to the population .And the fourth in Khuzestan Province after cities of Ahwaz, Dezful and Abadan. (2).

Table 2. SWOT Matrix

\begin{tabular}{lll}
\hline SWOT Matrix & Strengths(S) & Weaknesses(W) \\
\hline & $\begin{array}{l}\text { Strategies that, based } \\
\text { on the strengths, are } \\
\text { founded to take } \\
\text { advantage from } \\
\text { Opportunities (SO). }\end{array}$ & $\begin{array}{l}\text { Strategies that based on } \\
\text { diminishing weaknesses are } \\
\text { founded to take advantage } \\
\text { from opportunities (WO). }\end{array}$ \\
& $\begin{array}{l}\text { Strategies that based } \\
\text { on the strengths are } \\
\text { founded to combat } \\
\text { the threats (ST). }\end{array}$ & $\begin{array}{l}\text { Strategies that based on the } \\
\text { weaknesses, are founded to } \\
\text { combat threats (WT) }\end{array}$ \\
\hline
\end{tabular}

The old and worn-out texture of Shushtar has 176 ha. area which is located almost at the center of the city and the four boundaries of it are: from the north, Shahid Sherafat Street, from the south, Shahid Rejaei Street, from the east, Shahid 
Shariati and Imam, Khomeini Streets and from the west, Taleghani Street. Considering the main business and economic activities being concentrated in this area which include all the shopping centers of the city like Bazaar and insurance offices and banks, wholesalers and retailers...., the concentration and over crowdedness is well visible in this area (same source,6).

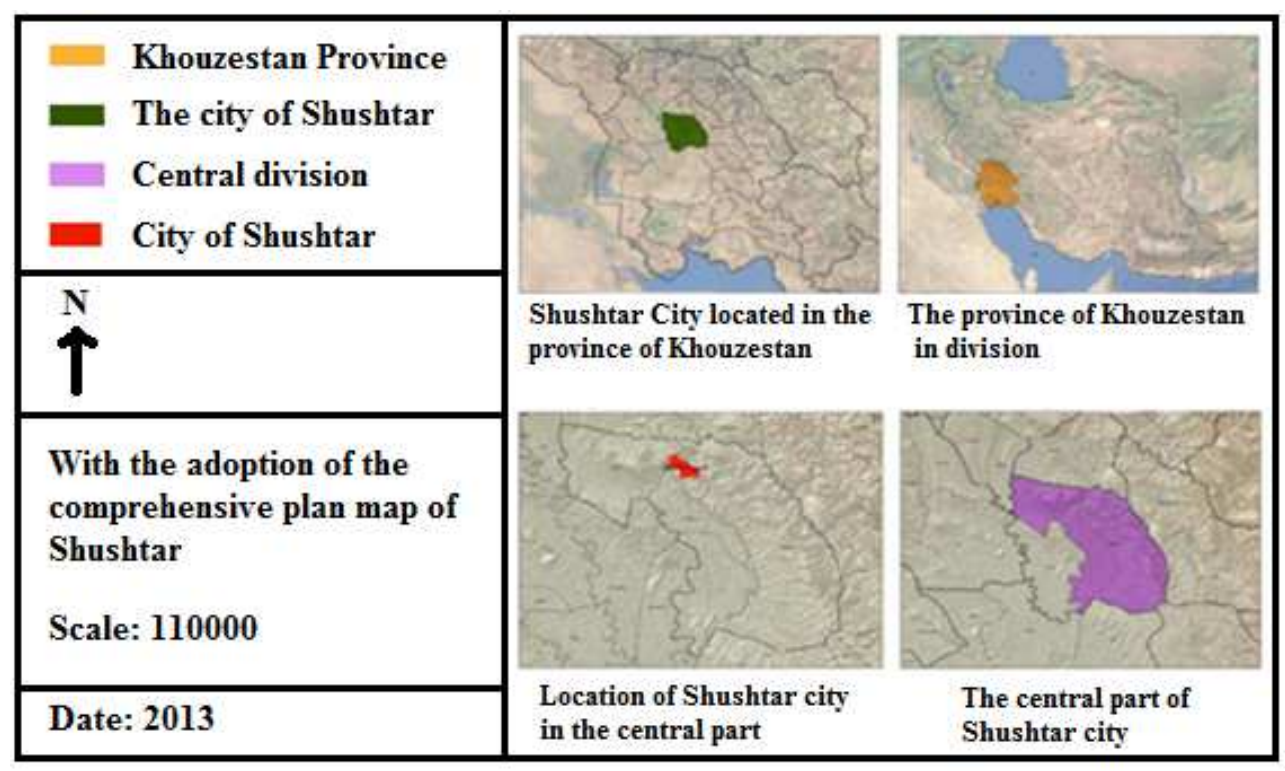

Fig. 1. Political divisions of Khuzestan Province

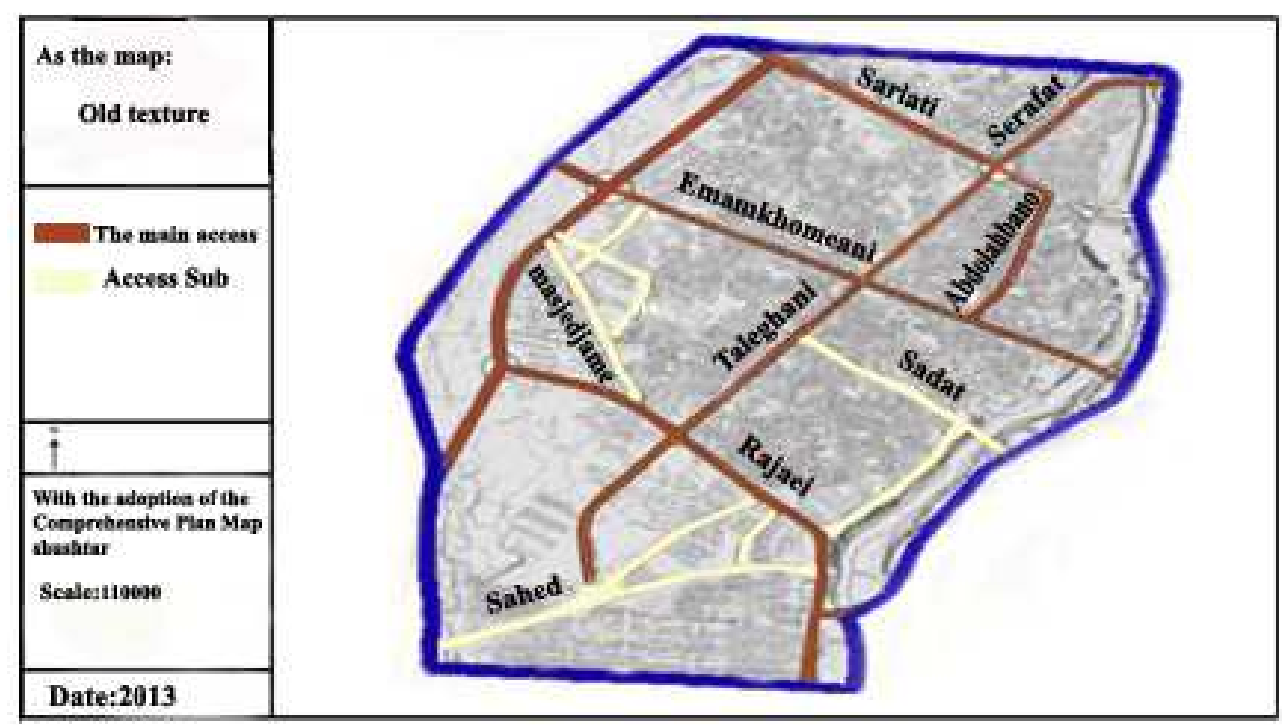

Fig. 2. Map of worn-out part of the Shushtar City

In the designed query, 4 general questions are asked which include, gender, education, age, career position. In this section we will analyze the data related to these questions.

1 -The results of investigation into the quality of the buildings show that only $8.82 \%$ of buildings are recently built and live able and nearly $70 \%$ are completely worn or should be destroyed.

2-The investigation into the quality of construction material used in residential units of the worn texture, is among the indices which enables to analyze the fabric situation of the texture. The results and field studies show that $7.64 \%$ of houses of worn-out texture possess brick and steel material, $52.35 \%$ possess brick, wood and mud, $34.1 \%$ possess brick, steel, wood, mud and $5.88 \%$ possess reinforced concrete material. The oldness of texture depends to a great degree on the age of the buildings. One of the characteristics of the old textures is the presence of old buildings. The results of the field studies show that $5.88 \%$ of the residential units, in the worn-out texture of Shushtar City do have an age less than 5 years, $7.64 \%$ an age of $5-10$ years, $14.7 \%$ an age of $10-15$ years ,20\% an age of $15-20$ years and the last $51.76 \%$ of buildings possess an age more than 20 years.

3-In investigation of the main problems of the neighborhood and based on the field studies, it is observed that $36.47 \%$ of people mentioned shortage of services 
andeducation, $12.94 \%$ mentioned social and cultural problems, $22.35 \%$ mentioned economic problems, $7.64 \%$ mentioned environmental problems as the main obstacles.

4-In investigation of the kind of problems of the neighborhood, in improvement and reconstruction and based on the field studies, we can conclude that $24.11 \%$ have mentioned resistance to natural hazards , $45.29 \%$ have mentioned narrowness of passages and lack of access to material for improvement tasks, $8.23 \%$ have mentioned the age of buildings and juridical problems, $4.7 \%$ have mentioned the smallness of land parcels and atlast $17.64 \%$ have mentioned the lack of willingness for improvement and renovation as the main factors for not to achieve improvement tasks.

\section{SWOT Analysis}

From this model view, appropriate strategies, maximize the strengths and opportunities and minimize weaknesses and threats. At this stage, based on the information from previous studies and investigations and by considering theories and views of experts and test assumptions, the guidelines and general and specific policies in every index for the purpose of reconstruction of the worn-out texture of Shushtar City, to reduce disaster risk, will be presented.

Table 3. Analysis of internal factors in the Strengths

\begin{tabular}{|c|c|c|c|}
\hline Strengths & weaknesses & opportunities & threats \\
\hline $\begin{array}{l}\text { Oldness of residence } \\
\text { In the neighborhood. } \\
\text { Presence of historical And precious } \\
\text { buildings in the neighborhood. } \\
\text { Political and social } \\
\text { History. } \\
\text { Presence of social institutions in the } \\
\text { neighborhoods. } \\
\text { Low rates of rent and price of } \\
\text { houses. } \\
\text { Possessing willingness of } \\
\text { partnership and cooperation in } \\
\text { improvements and renovations of } \\
\text { neighborhood. } \\
\text { Low noise pollution in the } \\
\text { neighborhood. } \\
\text { Private ownership of real estates. } \\
\text { Existing low rise buildings. } \\
\text { Existing local councils. }\end{array}$ & $\begin{array}{l}\text { Intense weariness in the fabric } \\
\text { texture of the neighborhood. } \\
\text { Low income and economic level of } \\
\text { the employees. } \\
\text { Population evasion. } \\
\text { Lack of strength of buildings } \\
\text { against natural disasters. } \\
\text { Narrow alleys and passages. } \\
\text { Low strength of buildings against } \\
\text { natural risks. } \\
\text { Non-standard material used in most } \\
\text { the buildings. }\end{array}$ & $\begin{array}{l}\text { Economic saving through } \\
\text { reconstruction of this part. } \\
\text { Existing laws related to broadening } \\
\text { of the passages. } \\
\text { Possibility of reinstatement of space } \\
\text { and fabric. } \\
\text { Possibility of utilizing patterns of } \\
\text { precious architectural buildings in } \\
\text { the new designs. } \\
\text { Ease of possessing buildings } \\
\text { because of weariness and low } \\
\text { strength of them, low intensity and } \\
\text { low price. } \\
\text { Determination of authorities to } \\
\text { intervene for reconstruction. } \\
\text { Existing multitude of global and } \\
\text { internal experiences in } \\
\text { reinstatement and revival of worn } \\
\text { textures. }\end{array}$ & $\begin{array}{l}\text { Continuation of Population evasion. } \\
\text { Weak authority of local } \\
\text { management. } \\
\text { Lack of incentive practices } \\
\text { Intense population concentration } \\
\text { during day and it's evacuation at } \\
\text { night. } \\
\text { Not considering people's } \\
\text { partnership. } \\
\text { Intense reduction in social security. } \\
\text { Increase in poverty and un- } \\
\text { employment rates among residents } \\
\text { of the texture. } \\
\text { Non uniformity between new } \\
\text { constructions and the old structure. }\end{array}$ \\
\hline
\end{tabular}

Table 4. Analysis of internal factors in the Strengths

\begin{tabular}{|c|c|c|c|}
\hline Strengths & Weight & Ranking & Score \\
\hline $\begin{array}{l}\text { Oldness of residence } \\
\text { In the neighborhood }\end{array}$ & 0.05 & 3 & 0.15 \\
\hline Presence of historical And precious buildings in the neighborhood. & 0.05 & 3 & 0.15 \\
\hline Existing Social institutions of the neighborhood. & 0.06 & 2 & 0.12 \\
\hline Existing local councils. & 0.06 & 3 & 0.18 \\
\hline Possessing willingness of partnership and cooperation in improvements and renovations of neighborhood. & 0.07 & 4 & 0.28 \\
\hline Low noise pollution in the neighborhood & 0.03 & 2 & 0.06 \\
\hline Existing low rise buildings & 0.04 & 2 & 0.08 \\
\hline Private ownership of real estates. & 0.05 & 2 & 0.10 \\
\hline $\begin{array}{l}\text { Political and social } \\
\text { History }\end{array}$ & 0.06 & 4 & 0.24 \\
\hline Low rates of rent and price of houses. & 0.03 & 2 & 0.06 \\
\hline
\end{tabular}

Table 5. Analysis of internal factors in the Weaknesses

\begin{tabular}{llll}
\hline Weaknesses & Weight & Ranking & Score \\
\hline Intense weariness in the fabric texture of the neighborhood. & 0.08 & 4 & 0.32 \\
Low income and economic level of the employees. & 0.06 & 4 & 3 \\
Population evasion. & 0.07 & 0.24 & 0.21 \\
Lack of strength of buildings against natural disasters. & 0.07 & 3 & 0.21 \\
Narrow alleys and passages. & 0.07 & 2 & 0.18 \\
Low strength of buildings against natural risks. & 0.05 & 2 & 0.14 \\
Non-standard material used in most the buildings & & \\
\hline
\end{tabular}


Table 6. Analysis of external factors in the Opportunities

\begin{tabular}{llll}
\hline Opportunities & Weight & Ranking & Score \\
\hline Economic saving through reconstruction of this part. & 0.09 & 4 & 0.36 \\
Existing laws related to broadening of the passages. & 0.08 & 4 & 0.32 \\
Possibility of reinstatement of space and fabric & 0.07 & 3 & 0.21 \\
Possibility of utilizing patterns of precious architectural buildings in the new designs. & 0.06 & 2 & 0.12 \\
Ease of possessing buildings because of weariness and low strength of them, low intensity and low price. & 0.04 & 2 & 0.08 \\
Determination of authorities to intervene for reconstruction. & 0.05 & 2 & 0.10 \\
Existing multitude of global and internal experiences in reinstatement and revival of worn textures. & 0.05 & 2 & 0.10 \\
\hline
\end{tabular}

Table 7. Analysis of external factors in the Threats

\begin{tabular}{llll}
\hline Threats & Weight & Ranking & Score \\
\hline Continuation of Population evasion. & 0.08 & 4 & 0.32 \\
Weak authority of local management. & 0.06 & 4 & 0.24 \\
Lack of incentive practices & 0.06 & 3 & 0.18 \\
Intense population concentration during day and it's evacuation at night. & 0.05 & 2 & 0.10 \\
Not considering people's partnership. & 0.04 & 2 & 0.08 \\
Intense reduction in social security. & 0.06 & 0.12 \\
Increase in poverty and un-employment rates among residents of the texture. & 0.06 & 3 & 0.18 \\
Non uniformity between new constructions and the old structure.. & 0.04 & 3 & 0.12 \\
\hline
\end{tabular}

\section{Discussion and Conclusion}

Among the most important consequences of rapid growth of urbanization in Iran, in addition to inappropriate urban infrastructures for the residents and urban emigrants, is the formation of irregular and problematic intra-urban textures and ultimately the high factor of risk-taking, which has had many challenges .This problem alongside the issue of land, becoming a scarce economic resource in recent decade, has caused that optimum use of old and worn-out textures (dead and non used urban spaces), which is one the main sources of land supply, gains special importance. Establishment of one institution or strong team for intervention management in worn-out textures and also management of risks is recommended. Based on the surveys done among residents of the texture, concerning its reconstruction, one could remark that: The plan of reconstruction of old and worn-out textures of Shushtar City as many other urban projects face financial problems. Neglect of authorities toward this texture during many years and also lack of serious measures in the implementation of the project, has caused distrust of the residents. Renovation and reconstruction of old texture to reduce risk-taking in them, is possible only through the cooperation and partnership of the people. Therefore reconstruction of these worn-out textures should be done by the municipality and cooperation of Cooperative-company, and this will be realized only when the municipality possesses adequate credits for these issues. What that could be derived from the referred discussions are as follows:

\section{The Results of Research Assumption}

Considering that low quality and nondurable material is used in the most of the existing buildings, Renovation in these textures could be a good practice for reducing risktaking in theses region. As nearly $70 \%$ of buildings are completely worn-out, $52.35 \%$ of houses have brick, wood and mud material, $51.76 \%$ of buildings are more than 20 years old, $36.47 \%$ of people have problems to achieve construction and $45.29 \%$ is the rate for narrowness of passages and lack of access to material for improvement, therefore one could conclude that the assumption that "reconstruction in the worn-out texture of Shustar City could be a good practice to reduce risk-taking" is confirmed.

\section{Offering Appropriate Concepts and Recommendations in Reconstruction of Worn-Out Texture of Shushtar City}

Real partnership of people in the projects and plans related to the revival and reinstatement in different dimensions, retrofitting of buildings within the texture and reducing the natural hazards risks, attempts to strengthening and restoration of buildings and historical monuments, pavement of the bed of passages with good and durable material, mitigation in reconstruction charges for buildings with non durable material(wood and mud), providing discounts in taxes for buildings' owners in order to begin the improvement and renovation tasks. Loans granted with low interest rates and with long terms to owners because of their financial in abilities to renovate their houses, attempts to eliminate obstacles, and solving problems and laws that have become obstacles to give speed to renovation and reconstruction of these textures, attraction of investors to accomplish improvement of textures, reconstruction and improvement in these neighborhoods to give neighborhood identity and reduce their risk taking against accidents, emphasis and supervision of urban management to widen passages within the textures, encouraging activities by municipalities, related organizations and people to reconstruct worn-out textures and reduction of risk taking in them, applying encouraging effective policies in regions that need retrofitting through the support, protection, maintenance, observation, strengthening and repair, establishment of one mediator organization to coordinate among the components 
of reconstruction cycle(people, banking system, government and municipality) and facilitation of reconstruction, identification and prioritizing of buildings with respect to different kinds of instabilities with the help of municipality and partnership of people.

\section{References}

[1] Shahidi, Akram, (2009), Social consequences of development and modernization of space for residents and local businesses Tabarestan central city of Mashhad. M.S Thesis, , Earth Sciences Faculty, Univ. Shahid Beheshti.

[2] Master Plan of Shshtar City, 2012, Tarh va Tadvin Consulting Engineers, Housing and Urban Development Organization of Khuzestan Province.

[3] Shamaaei, E, Poor Ahmad, Ahmad, Urban improvement and renovation from the view point of Geography, Tehran Univ. publications, 2006

[4] Peter Dickens (2004), Urban Sociology, Community, local gathering and its nature, Mashhad, Astane Ghodse Razavi.
[5] Habibi et al. (2008), improvement and renovation of old urban textures, Kurdistan Univ. Publications.

[6] Zebardast,Esfandiar(2006), Application of AHP in Planning, Fine Arts Quarterly, No. 1 ,pg(4-56).

[7] Rules and regulations of the city,(2006), Housing and Urban Development Ministry 2006, Supreme Council of Planning and Architecture Secretariat

[8] Mohammad Farhadi Consultant to the Red Crescent Population Manager, Chief Consultant of U.N in Risk taking management, 2013, Quarterly Journal of Rescue and Relief, 4 th year, No. 3, 108-110.

[9] Shamaaei, Ali \& Poor Ahmad, (2005), an analysis of urban policies and programs of improvements and renovations in national development programs, Quarterly of Geographical Research, No. 48, 112.

[10] Ha seong, Kyu (2001), developing a Community-Based Approach to Urban Redevelopment, GeoJournal

[11] John Diamond, Joyce Liddle, Alan Southern and Philip Ose,(2010), Urban Regeneration Management International Perspectives, Routledge 